Kapliyenko-lliuk Yuliya

$\mathrm{PhD}$ in Arts, associate professor, doctoral student of the A. V. Nezhdanova Odessa

State Musical Academy

yuliyakaplienko@gmail.com

ORCID 0000-0002-6114-9680

\title{
VIOLIN TRANSCRIPTIONS AS ONE OF THE METHODS OF YURI GINA'S PRACTICE AS A COMPOSER
}

The purpose of the paper is to analyse and characterize one of the fields of work of Yuriy Gina - violin cover versions, interpretations and transcriptions; to reveal the peculiarities of the Bukovynian composer's work on the borrowed material. Methodology. The methods of historical-cultural, theoretical and genre-style analysis were used and allowed to determine the basic principles of covering the works of other composers in the creative work of $Y$. Gina. The scientific novelty consists in scientific understanding of the process of development of professional musical art of Bukovyna; in revealing peculiarities of creative thinking of the composers of the region; in clarifying the principles of violin music of the region; in the analysis of music by Y. Gina, whose works have not been sufficiently studied in contemporary musicology. Conclusions. Particular importance in the creative work of Yuriy Gina is acquired by the works intended to be performed by the violin or by ensemble violin composition, which is closely linked with the performer's activities of the composer. Among the works of $Y$. Gina quite distinguishable are the cover versions and interpretations of the works of other composers. As a result of the analysis of this field of the artist's work, the basic principles of work on the borrowed material were discovered and there was determined relevance of this genre type to transcriptions. It has been mentioned that the purpose of this composer experiment was not only the replenishment of the repertoire for the violin and the violin ensemble, but also the desire to reinterpret the content and components of the musical form in a new way, to add virtuosity to works that were intended for another composition of performers. Consequently, on the basis of violin transcriptions of $Y$. Gina, one can identify the features of an individual style of the composer.

Key words: violin transcriptions, violin cover versions, interpretations for violin, composers of Bukovyna, Yuriy Gina.

Каплієнко-Ілюк Юлія Володимирівна, кандидат мистецтвознавства, доцент, докторант Одеської національної музичної академії ім. А. В. Нежданової

Скрипкові транскрипції як один з методів композиторської практики Юрія Ґіни

Мета статті - аналіз і характеристика однієї з галузей творчості Юрія Ґіни - скрипкових обробок, перекладень та транскрипцій; виявити особливості роботи буковинського композитора над запозиченим матеріалом. Методологія. Застосовано методи історико-культурологічного, теоретичного та жанрово-стильового аналізу, що дозволило визначити основні принципи обробки творів інших композиторів у творчій діяльності Ю. Ґіни. Наукова новизна полягає у науковому осмисленні процесу розвитку професійного музичного мистецтва Буковини; у виявленні рис творчого мислення композиторів краю; у з'ясуванні засад скрипкової музики регіону; в аналізі музики Ю. Ґіни, творчість якого не достатньо досліджувалась у сучасному музикознавстві. Висновки. Особливої ваги у творчому доробку Юрія Ґіни набувають твори, призначені для виконання на скрипці або ансамблевим скрипковим складом, що тісно пов'язано з виконавською діяльністю композитора. Серед творів Ю. Ґіни помітно виділяються обробки та перекладення творів інших композиторів. В результаті аналізу даної сфери творчості митця було виявлено основні принципи роботи над запозиченим матеріалом та визначено належність цього жанрового типу до транскрипцій. Зазначено, що метою даного композиторського експерименту стало не тільки поповнення репертуару для скрипки та скрипкового ансамблю, але й прагнення по-новому інтерпретувати зміст та складові музичної форми, додати віртуозності творам, котрі були призначені для іншого складу виконавців. Отже, на основі скрипкових транскрипцій Ю. Ґіни можна виявити риси індивідуального стилю композитора.

Ключові слова: скрипкові транскрипції, скрипкові обробки, перекладення для скрипки, композитори Буковини, Юрій Ґіна.

Каплиенко-Илюк Юлия Владимировна, кандидат искусствоведения, доцент, докторант Одесской национальной музыкальной академии им. А. В. Неждановой

Скрипичные транскрипции как один из методов композиторской практики Юрия Гины

Цель статьи - анализ и характеристика одной из отраслей творчества Юрия Гины - скрипичных обработок, переложений и транскрипций; выявить особенности работы буковинского композитора над заимствованным материалом. Методология. Применены методы историко-культурологического, теоретического и жанровостилевого анализа, что позволило определить основные принципы обработки произведений других композиторов в творческой деятельности Ю. Гины. Научная новизна заключается в научном осмыслении процесса развития профессионального музыкального искусства Буковины; в выявлении черт творческого мышления композиторов края; в выяснении основ скрипичной музыки региона; в анализе музыки Ю. Гины, творчество которого недостаточно исследовано в современном музыковедении. Выводы. Особое значение в творчестве Юрия Гины приобретают произведения, предназначенные для исполнения на скрипке или ансамблевым скрипичным составом, что тесно связано с исполнительской деятельностью композитора. Среди произведений Ю. Гины заметно выделяются обработки и переложения произведений других композиторов. В результате анализа данной сферы творчества музыканта были выявлены основные принципы работы над заимствованным материалом и определена принадлежность этого жанрового типа к транскрипции. Указано, что целью данного композиторского эксперимен- 
та стало не только пополнение репертуара для скрипки и скрипичного ансамбля, но и стремление по-новому интерпретировать содержание и составляющие музыкальной формы, добавить виртуозности произведениям, которые были предназначены для другого состава исполнителей. Итак, на основе скрипичных транскрипций Ю. Гины можно обнаружить черты индивидуального стиля композитора.

Ключевые слова: скрипичные транскрипции, скрипичные обработки, переложения для скрипки, композиторы Буковины, Юрий Гина.

Relevance of the research. Yuriy (Georgiy) Mykolayovych Gina is a contemporary Bukovynian composer, teacher, violinist, conductor, public figure, composer of chamber-instrumental, orchestral and vocal music. Among the works of Gina the works for violin prevail, accompanied by the piano and violin ensembles. He is considered to be one of the founders of professional art in Bukovyna, in particular a violin school. As a director and leading teacher of one of the most prestigious musical schools in Chernivtsi, Y. Gina sought to enrich the repertoire of the younger generation of violinists. Therefore, the composer wrote not only original works, but he also made cover versions, transcriptions and interpretations of popular works of various composers of the present and the past.

Analysis of recent research and publications. The works of the composers of Bukovyna have not been sufficiently studied. The existing textbooks on the history of music consider the development of musical culture in Bukovyna in the context of general characteristics of Western Ukrainian music. However, in musicology literature, there is no separate study of the culture of the region, especially its contemporary artists. The collective work of the scientists of the music department of Y. Fedkovych Chernivtsi National University has become the source of the history of musical culture and education of Bukovyna [9]. There are quite a lot of publications in the periodical press on the performing, pedagogical and public activities of Yuriy Gina, made by O. Zalutsky [12], in reference journals, in separate sections of manuals and reviews on author's musical publications. However, these investigations do not study the style of the composers of Bukovyna, and do not provide sufficient analysis of the creative work of $Y$. Gina.

The objective of the study is to analyse and characterize one of the fields of the creative work of Yuriy Gina - violin cover versions, interpretations and transcriptions and to reveal the peculiarities of the work of Bukovynian composer on the borrowed material.

Research findings. Yuriy Gina turned to a special kind of creative work - transcriptions of famous works of other composers. Y. Gina introduces his cover versions and interpretations for the violin, as the author himself calls them, into the practice of violinists, on the one hand, enriching the repertoire, and on the other hand - updating all familiar works with the means and techniques of violin performing art. "Violin transcriptions, - as N. Mironova mentions, - is an important part of the entire sphere of transcription art, which combines composing and performing creative work. This genre formation seems to mean the peculiarity of contemporary musical process, because here the singer is often a composer, who creates a field of free interpretation that is based on recognizable musical texts" [10, 408]. Indeed, it was Yuriy Gina's performing work that prompted him to work actively in the field of covering the works of other composers. In defining the genre of this type of composer's work, we refer to the concept of "transcription". Many scientists studied this phenomenon, in particular M. Borysenko [2], B. Borodin [3], O. Zharkov [4], N. Ivanchey [5], G. Kogan [6], N. Mironova [10], V. Rudenko [11] and others. According to the majority of researchers, the main concept that conveys the essence of composer transformations of music of another kind of existence is "transcription". Thus, G. Kogan [6] divides this category into different types of covering, therefore, as N. Mironova points out, "such concepts as transcription, interpretation, covering, arrangement, free covering, paraphrase, fantasy etc., are set in musicology literature and performing practice" [10, 411]. Transcription - from Latin means "rewriting" - has several interpretations, among which is this one: "adaptation of a work for another performer, his/her arrangement" [13, 274]. The researcher O. Bereghova defines transcription as "interpretation, cover version of a musical composition that has an independent artistic value" [1,440]. So, such definitions of this phenomenon in music give grounds to define violin interpretations of Y. Gina as "transcriptions". Among the masters of transcriptions of different generations there are F. Liszt, R. Schumann, F. Busoni, Cl. Debussy, M. Ravel, B. Bartok, S. Prokofiev, S. Rachmaninoff, I. Stravinsky, D. Shostakovich, R. Shchedrin and others. On the basis of the borrowed works of other composers, violin transcriptions of violinists of the twentieth century were created, including G. Venyavsky, E. Ysaÿe, J. Joachim, F. Kreisler, P. Kokhansky, P. Sarasate, J. Heifetz, D. Tsiganov, E. Tsimbalist and many other artists. Among contemporary Ukrainian violinists, who turned to transcriptions of works of other composers, one can distinguish a talented Ukrainian violinist B. Kotorovych. His transcriptions of works of G. Kancheli, A. Pärt and E. Stankovich received positive comments from the authors of the original.

However, returning to the author's definition of this type of work on the borrowed musical material, as covering, let us consider this phenomenon in more detail. In the system of musical culture, covering, as L. Kostina notes, "is a specific sphere of creative realization of artistic values and the translation of sociocultural experience of creators, which contains and reproduces performing and composers' aspects". According to the researcher, "covering is simultaneously a mechanism of musical thinking and a means of its implementation and a specific result" [8, 293]. This phenomenon can be studied in a broad and narrow sense. In a broad sense, L. Kostina, sees musical covering, as "making any artistic idea "musical" (beyond musical 
phenomena) by means of creating a musical composition", and in the narrow one - the process of tuneharmonious, structural, compositional, and texture-dynamic development of a particular theme" [8, 293]. According to I. Y. Konovalova, cover has a multiple manifestation "in a number of genres related to the nature of musical art genres (transcription, interpretation, editing, etc.), united into a specific system of "secondary" author's interpretation of intonational primary sources" [7,61-62]. The main criteria by which one can characterize covers, as varieties of secondary genres, according to I. Konovalova, can be determined by: "1) the type of intonation-shaped model; 2) the nature of the "model - interpretation" ("primary - secondary") ratio; 3 ) the extent of the composer's renewal of the original" [7, 63-64].

Along with the work related to covers of the selected compositions, Gina makes their editing, which is reflected in the remarks to each transcription and is related to the needs and peculiarities of violin performing. Thus, according to $\mathrm{O}$. Bereghova's definition, one understands "introducing changes and additions to the musical recording of the musical composition, which facilitate its practical use, as well as the note recording of the composition itself with similar changes and additions" [1, 440]. In the case of Y. Gina's cover versions, his editing is approximate to transcriptions.

Yuriy Gina turned to interpreting the works that have long become the classics of world, Ukrainian, in particular Bukovynian, musical art. The composer treated the original with great respect, trying to preserve the original, its style, musical language, but tried to add the virtuoso component of play on the violin. The transcriptions created by Gina gave a new breath to the works, as they sounded in a new frame, in a new completeness of ensemble violin sound, and some musical themes in solo violin performance received a new colouring and, accordingly, new interpretation. Interpretations, transcriptions, editing of Gina, which are in fact independent types of musical cover in relation to work on the cited authors' compositions, at the same time, indicate different levels of "correlation of artistic interpretation and composition". "These synthetic, in their origin, genres, as noted by I. Konovalova, aim at creating a new version of fixed original composer works as source texts by changing their performing context - key-texture conditions, quantitative and qualitative features of the performing composition while maintaining content, structural and compositional, melodicthematic and tune-harmonic parameters" [7,67].

The majority of Y. Gina's transcriptions are intended for violin ensemble performing with piano accompaniment. On the basis of this principle of the author's interpretation, there were covered the works, which, in their original source, were associated with solo piano creative work, in particular, "Impromptus" by F. Schubert and "Lyrical Song" by M. Dremlyuga.

Y. Gina's appeal to "Impromptus", as a romantic play of free form, is connected with the general romantic trend of the composer's creative work, his essence and the peculiarity of worldview. He chooses genres that are in harmony with his lyrical nature, the elegance of style, and striving for beauty. "Impromptus" by F. Schubert in G Major, taken as a basis for Gina's cover version, is extremely lyrical, poetic and full of romantic experiences typical of the music of the Austrian composer and romanticism in general. The Bukovynian composer enriches the piano original texture with the sophisticated timbre of the violin, which gives the music a special intimate sound. In general, the author of the cover version adheres to the basic form, type of presentation, harmonic plan, but modifies metre-rhythm characteristics, where instead of 2/2 we see 4/4. This induces the composer to shred lengths, reducing them by half. Such a change affects the general character of the work, its tempo peculiarities, giving "Impromptus" more fluidity and speed of movement. However, the melodiousness of the theme, which the composer entrusts to the string instrument, is not lost he gradually increases the number of violin ensembles. The first theme is described in the original register of the first and the second violins. The melody of wide breathing sounded in a new, sincere and lyrical voice in the timbre play of the violin.

The main method of renovating the borrowed music material is covering the theme by creating other melodic lines for it, in particular, the contrast-polyphonic type, and the various supporting voices of the piano part. Sometimes the composer resorts to changing the register presentation of the thematic material, by which he achieves a special dramatic effect at the moment of culmination. The largest culmination part of the form in Gina's works is the general reprise, where the theme is set out in triple-voice ensemble with transfer of the melody one octave above and its saturation with the chord performance. Thus, the cover version of Y. Gina does not substantially change the original, but gives it a new colour, extending its life in a new interpretative form.

Another work, taken as a basis for the transcription of $Y$. Gina is a piano play from school repertoire "Lyric Song" by M. Dremlyuga. In this composition, Gina acts on the same principle as in "Impromptus": he entrusts performing the thematic material to the ensemble violin group. The theme is gradually enriched with a dense sound of three parts of string instruments, with peculiar general movement to the culmination in the reprise of the three-part form. The character of the part ratio is typical for Gina's covers, where, along with rich violin unison, elements of contrasting polyphonic strings are involved, which makes the texture moving and flowing. Creating this cover for the children's ensemble of violinists, accompanied by the piano, the composer does not burden the performance with complex and virtuoso elements, but gives the composition a new saturated sound with the help of simple techniques of playing string instruments.

Y. Gina resorted to covering the works for violin and piano, which he enriched with ensemble sound, adding the parts of the second and third violins. Among such samples is M. Lysenko's "Minute of Disap- 
pointment", the work that Gina arranged for two parts of violin with piano. The composer tried to dynamicize a simple two-part form of the original by means of compressing the texture and making more active other violins, which often create a contrast counterpoint with the part of the first violins, which invariably lead the main theme of the composition. The melodiousness and softness of intonations of the melody and its sincere character are sometimes emphasized by the folk third the second part in combination with the typical supporting bi-voice.

Among Gina's covers for the violin ensemble, we find the vocal masterpiece by A. Kos-Anatolsky "Oh, you Girl, from the Grain of a Nut", which the composer in his interpretation calls fantasy and designates for instrumental performing. The soft and tender intonations of the song easily adapt to the violin timbre, not in the least losing its sincerity. Gina interprets the fantasy for the song "Oh, you Girl, from the Grain of a Nut" taking for the basis the original three-part form laid down by the author, but, unlike the song verse, the composer chooses a more acceptable for instrumental music three-part form. However, the genre of fantasy, which foresaw some kind of improvisation, and, therefore, a rather free structure of form, did not affect the character of the structure. The clear complex three-part form demonstrates the features of all its components, however no significant contrast between the extreme parts and the middle part is observed - the form is single-themed, which is associated with the formation of the original. At the same time, the main means of creating a contrast between the sections becomes a key change, where the extreme parts are written in $G$ minor, and the trio - in the main key of the song $-\mathrm{C}$ minor. Between the parts the composer introduces small constructions-connections, which perform the functions of melodic-harmonic modulations. Y. Gina "improvises" in his own way, leaving the main thematic line unchanged, however he replaces the size of $6 / 4$ by $6 / 8$, giving a greater boost to the character of the instrumental performance. In addition, gradual compression of the texture, with a characteristic increase in the number of voices, saturation of the piano accompaniment with chord performance in a dynamic reprise, gives the section an active culmination.

A more detailed composition for the children's violin ensemble with the piano, where Y. Gina engages all age groups of pupils in performing - from junior to senior musical school - becomes "Ancient Romance", based on "Romance" from musical illustrations to the story of O. Pushkin "Zametil (Snowstorm)" by G. Sviridov. Interpreting this work for ensemble performance, the composer did not violate the main ideas of the author of the work. He left unchanged the form, the harmony, the couplet structure, the main thematic intonations and the characteristic supporting voice elements. In general, the composition consists of five main sections with the introduction, which forms a clear couplet-variation form. The main theme of the romance in all verses is invariable and demonstrates a certain melodic ostinato character. The main method of variation is the texture modification, which is based on various duplications of the melody, vertical rearrangements, the use of supporting voices, formation of polyphonic contrasting polyphony. The composition starts with a traditional short introduction, which is entrusted to all parts of the ensemble. The five sectionscouplets of the form build a distinct ordonnance in dramaturgic development, where the first three accumulate dynamics due to the gradual increase of voices, compression of the texture, which leads to the fourth the culmination couplet of the form. The applied methods of division of voices, chord performance, the use of extreme registers and loud dynamics, contribute to the increased dramatic effect. The final section of the form does not lose ostinato theme, but it is entrusted to the piano performing, thus emphasizing the importance of all the members of the ensemble. Sharp fading of dynamics, disconnection of voices, high register of strings on $p p$, the supporting voices of muted violins give mystery and impressions of echo and memories. The final section of the form serves as a peculiar conclusion, a coda. Thus, the work of $G$. Sviridov, designed in the original for the orchestra, was successfully covered by Gina for the violin ensemble, not in the least losing its original beauty, but on the contrary, it acquired a chamber lyrical and sincere character.

As the basis for another cover version of a composition for the ensemble of violinists $Y$. Gina used a symphonic idyll "In the evening" by the Czech composer Z. Fibich. The violin transcription of this work, known as the "Poem" by the famous Czech violinist R.J. Kubelik, became well-known. Gina retains this title for his version of a cover, but adapts the composition to the violin ensemble, accompanied by the piano. An extremely gentle and romantic play with hidden three-part dancing character, resembles salon music of the nineteenth century with its chamber sound, a tendency to miniature, in the basis of which there is deep and mysterious lyrics. No wonder there is a number of different editions, interpretations and transcriptions for various performers, including solo piano, violin and piano, string ensemble, trumpet with piano. Soft, rounded intonations endow the theme with femininity and aristocratic sophistication. Despite the fact that the music transcriptions of the "Poem" occur in various key variants (C-dur, Des-dur, D-dur), Gina keeps the most complex, original version of the key of the composition - Des-dur. After all, key plays, in many cases, an essential role in creating the image, the character of the composition. The author of the cover, with peculiar to him caution, treats the fundamental principle: trying to change the main features and elements of the composition as little as possible, he enriches the musical canvas with polyphonic techniques of development, in combination with typical features of a homophonic-harmonious style, by which he demonstrates the skill of mastering the methods of violin ensemble writing.

The composition begins with a small seven-time introduction, which Gina entrusts to the piano part. The main thematic structure of the composition is comprised in a one-part composition, which, however, is not devoid of internal division into sections. Each wave of development, reaching its local culmination, gains 
new melodic peaks. The melodic-syntactic basis of the structure - shredding with closure - develops the laid down image best of all, since it also contains a display of the main themes, and its development at a new height, and development at the moments of shredding, and summing up simultaneously with the culmination of the composition, and the final, cadence element, which logically completes a small one-part composition. The author of the cover in the same way gradually saturates the texture of the violin ensemble, increasing the number of voices at the moments of culmination development.

Among the transcriptions of the Bukovynian composer there are also works devoted to solo performing on the violin with the accompaniment of the piano. Some of these compositions, according to the author, can be performed without accompaniment. Thus, in particular, "Fantasy for S. Vorobkevich's song "Let's Play, Gypsy Old"", dedicated to the grandson of Y. Gina - Maryan, has two variants of performing - with piano accompaniment and without one. Describing the first variant, it should be noted that the fantasy begins with a small piano accompaniment of the choral composition, the basis of which theme is the refrain to the song. The main key of the composition - E minor - is already in the beginning coloured with the altered chords of the double dominant, thereby emphasizing composer's own interpretation of the borrowed musical work. S. Vorobkevich's song, in spite of a fairly large number of verses, in Y. Gina's cover is limited, in fact, by two verses, which form a non-contrast two-part form with signs of a tripartite; if we consider this structure within a simple form, then this type of form can be defined as a simple two-part reprise form. Not for the first time choosing the genre of fantasy for his transcription, the composer demonstrated a certain degree of stability in the selection of the principles of covering the song material, as it is in this genre that he most demonstrates the ability to improvise, enriching the melody with the peculiar violin techniques of the play, which demonstrate virtuosity of the instrument. The first section of the form - the first couplet of the song, forms a two-part form, consisting of a chant and a chorus, which is repeated twice. The composer does not change the original composition of the song, only when rehearsing the chorus he immediately resorts to enriching the melody with peculiar violin passages glissando, broad melodic jumps, fast upward arpeggio with stops on long sounds and free interpretation of the rhythm and tempo, which, on the one hand, is justified by the improvisation character of the genre basis of transcription, and, on the other hand - characterizes the song genre, which represents the features of Ukrainian soloists. The second section of the form immediately differs with the introduction of the key contrast: the composer without pre-training begins the second verse of the song in the key of the dominant (B minor). The theme sounds in higher register, both the tempo (Piu mosso) and the nature of performing the violin part and accompaniment quicken. Using the technology of a two-voice play on the violin, Gina complicates the theme with a supporting voice of tremolo, giving anxiety in development, which contributes to the gradual dynamization of the form and culmination, at the moment when the exciting tremolo stops, but a contrasting polyphonic two-voice is formed. The repetition of the refrain sharply switches the theme into the main key of the composition, contributing to completeness of the form.

Y. Gina also presented a cover version and editing of the composition of a famous Romanian composer Ciprian Porumbescu - "The Ballad", known as a composition intended for solo performing on the violin with the accompaniment of the piano or orchestra. Gina retains the original author's idea, leaving the main composition of the performers (violin and piano) unchanged, the main thematic load, the principles of the development of the material, the original national Romanian colouring of the melodies with its ornamentation and tune-harmonious basis. However, Gina sometimes adds ornamental decorations, increasing virtuosity of the performing. It was this plan that prompted the composer to change the form of the composition: in an effort to add improvisation, Gina expands the structure due to the variational repetition of the first section of the middle of the complex tripartite form. This section in the cover of the Bukovynian composer becomes the culmination, the most virtuoso part, which gives the composition of $\mathrm{C}$. Porumbescu greater dynamics and dramatic effect. In addition, Gina changes the interpretation of simple forms within the complex one. Thus, he replaces the reprise-free three-part character of the first section of the form with a reprise one, combining the middle part and the reprise into one structure, and as a reprise, he added the exact repetition of the first section. Gina compensates the shortened reprise of the entire form with a small coda, which adds logical completeness. However, Gina's cover version loses the author's introduction, which, however, could have set, to some extent, the soloist to the beginning. We can assume that in this way, the composer sought not to overload the composition, extended with interpretative changes. Thus, the form of the "Ballad" by Porumbescu in the cover version of $Y$. Gina due to the transformation of the internal structure of the sections of the form, where the composer substitutes the signs of reprise-free and two-part form with a more logical three-part form, acquires completeness and ordonnance, emphasizes the most melodic and intonationally expressive sections of the composition.

Conclusions. The principles of Y. Gina's work on the borrowed material have several tendencies. Renovations of the already existing compositions, meant for various performers, are adapted by the composer to the violin or ensemble of violinists, accompanied by piano. His cover versions, interpretations, as they are called by the author, may correspond to and be determined by the phenomenon of "transcription", since the "secondary" formations in the creative interpretation of Gina originated on the basis of typical working methods characteristic of transcriptions. In addition, almost all of the artist's cover versions were subject to author's editing. We shall note the main methods of covering the borrowed compositions: the theme of the 
compositions is entrusted to the violin, enriching it with virtuosity of the instrument, the texture is saturated with ensemble sound, which leads to the creation of supporting voice polyphonic and contrast-polyphonic type of polyphony. At the same time, the composer experiments with the structure, the key plan and the metre rhythm of the compositions. Consequently, the creative searches of the contemporary artists of Bukovyna, their artistic plans and ideas require timely study and analysis, enabling young musicians and scientists to appreciate their heritage and comprehend the achievements of the past in a new way in a peculiar composer's interpretation.

\section{תimepamypa}

1. Берегова О. 24 каприси Нікколо Паганіні в образах сучасного майстра // Науковий вісник Національної музичної академії України ім. П.І. Чайковського. К. : НМАУ ім. П.І. Чайковського, 2013. Вип. 86 : Історія в особистостях. С. $437-448$.

2. Борисенко М. Ю. Жанр транскрипції в системі індивідуального композиторського стилю : автореф. дис. на здобуття наук. ступ. канд. мист-ва : 17.00.03 "Музичне мистецтво". Харків, 2005. 17 с.

3. Бородин Б. Б. Феномен фортепианной транскрипции : опыт комплексного исследования : автореф. дис. на соискание уч. степени канд. искусствовед. : 17.00.02 "Музыкальное искусство". М., 2006. 25 с.

4. Жарков О. М. Художній переклад в музиці : проблеми і рішення : автореф. дис. на здобуття наук. ступ. канд. мист-ва : 17.00 .02 "Музичне мистецтво". К., 1994. 19 с.

5. Иванчей Н. П. Фортепианная транскрипция в русской музыкальной культуре XIX века : автореф. дис. на соискание уч. степени канд. искусствовед. : 17.00.02 "Музыкальное искусство". Ростов-на-Дону, 2009. 32 с.

6. Коган Г. Предисловие. Школа фортепианной транскрипции. М. : Музыка, 1976. Вып. 2. С. 2.

7. Коновалова І. Ю. Жанрова система музичної обробки в хоровому мистецтві // Вісник Харківської державної академії дизайну і мистецтв. Мистецтвознавство. Архітектура. Харків, 2008. № 12. С. 61-69.

8. Костіна Л. М. Значення методу музичних розробок у процесі творчої діяльності // Актуальні проблеми державного управління, педагогіки та психології. Херсон, 2013. Вип. 2. С. 290-296.

9. Кушніренко А. М. Історія музичної культури й освіти Буковини : навч. посібник. Чернівці : Чернівецький нац. ун-т, 2011. 376 с.

10. Миронова Н. Скрипкова транскрипція та ії інтерпретація у композиторській і виконавській практиці (на прикладі творів Олега Безбородька) // Науковий вісник Національної музичної академії України ім. П. І. Чайковського. К. : НМАУ ім. П.І. Чайковського, 2003. Вип. 105.: На скрижалях музичної історії: українська музика та культурний процес. На пошану Маріанни Давидівни Копицію С. 408-424.

11. Руденко В. Концертная скрипичная транскрипция XX века и проблемы интерпретации // Музыкальное исполнительство. М. : Музыка, 1979. Вып. 2. С. 22-56.

12. Юрій Ґіна : Музичне краєзнавство Буковини. Хрестоматія : навчальний посібник до курсу "Музичне краєзнавство". Вип. 6. - Чернівці : Чернівецький нац. ун-т, 2009. 189 с.

13. Юцевич Ю. Є. Словник-довідник. Тернопіль : Навчальна книга, 2003. 352 с.

\section{References}

1. Bereghova, O. (2013). 24 Capricorn Niccolo Paganini in the images of a modern wizard. M. M. Skoryk (Eds.), Scientific Herald of the National Music Academy of Ukraine named after. P. I. Tchaikovsky. (Vol. 86), (pp. 437448). Kyiv: NMAU im. P.I. Chajkovsjkogho [in Ukrainian].

2. Borysenko, M. Ju. (2005). Genre of transcription in the system of individual composer style. Extended abstract of candidate's thesis. Kharkiv [in Ukrainian].

3. Borodin, B. B. (2006). Phenomenon of piano transcription: the experience of complex research. Extended abstract of candidate's thesis. Moscow [in Russian].

4. Zharkov, O. M. (1994). Artistic translation in music: problems and solutions. Extended abstract of candidate's thesis. Kyiv [in Ukrainian].

5. Ivanchey, N. P. (2009). Piano transcription in the Russian musical culture of the XIX century. Extended abstract of candidate's thesis. Rostov-na-Donu [in Russian].

6. Kogan, G. (1976). Foreword, Shkola fortepiannoy transkriptsii. (Vol. 2), (P. 2). Moscow: Muzyka [in Russian].

7. Konovalova, I. Ju. (2008). Genre system of musical processing in choral art. Bulletin of the Kharkov State Academy of Design and Arts. Musicology. Architecture. (№ 12), (pp. 61-69). Kharkiv [in Ukrainian].

8. Kostina, L. M. (2013). The value of the method of musical development in the creative process. Aktualjni problemy derzhavnogho upravlinnja, pedaghoghiky ta psykhologhiji. (Vol. 2), (pp. 290-296) Kherson [in Ukrainian].

9. Kushnirenko, A. M., \& Zalucjkyj, O. V., \& Vyshpinsjka, Ja. M. (2011). History of musical culture and education of Bukovina. Chernivci: Chernivecjkyj nac. un-t [in Ukrainian].

10. Myronova, N. (2003). Violin transcription and its interpretation in composing and performing practice (on the example of Oleg Bezborodko's works). O. V. Ghorodecjka (Eds.), Scientific Herald of the National Music Academy of Ukraine named after. P. I. Tchaikovsky. (Vol. 105), (pp. 408-424). Kyiv: NMAU im. P. I. Chajkovsjkogho [in Ukrainian].

11. Rudenko, V. (1979). Concert violin transcription of the XX century and problems of interpretation. Muzykalnoe ispolnitelstvo. (Vol. 2), (pp. 22-56). Moscow: Muzyka [in Russian].

12. Zalucjkyj, O. V. (Eds.). (2009). Yuriy Gina: Bukovinian Music History, Textbook: a textbook for the course "Music Local Studies (Vols. 6). Chernivci: Chernivecjkyj nac. un-t [in Ukrainian].

13. Jucevych, Ju. Je. (2003). Dictionary-directory. Ternopilj: Navchaljna knygha [in Ukrainian].

Стаття надійшла до редакції 26.05.2018 p. 